\title{
Isomerization and Evaporation of Red Sorghum Hydrolyzate Sugar into Fructose Syrup through Water and Ethanol-Water as the Media
}

\author{
aPermanasari, A.R.*, a'Yulistiani, ${ }^{\mathrm{a}} \mathrm{F}$, Gustaji, ${ }^{\mathrm{a}} \mathrm{R} . \mathrm{F}$, Karisma, ${ }^{b}$ Wibisono, W. \\ aDepartement of Chemical Engineering, Politeknik Negeri Bandung, Bandung 40559, Indonesia \\ bepartment of Midwefery, STIKES Patria Husada Blitar, Blitar 66137, Indonesia
}

Received 12 August 2019; accepted 20 December 2019

\begin{abstract}
Red sorghum flour has considerable potential to be used as fructose syrup. The process of making fructose syrup was started with making hydrolyzate sugar by enzymatic hydrolysis of the polysaccharide into glucose syrup, then being isomerized using glucose-isomerase into fructose syrup. The study aimed to determine the best temperature in the isomerization process of hydrolyzate sugar from red sorghum flour through water and ethanol-water as the media and determine the optimum temperature of evaporation process to produce fructose syrup appropriate with SNI and HFS 42 commercials products. Isomerization was carried out on water media and ethanol-water media (2.5: 1) with temperature variations of $27^{\circ} \mathrm{C}, 40^{\circ} \mathrm{C}$ and $60^{\circ} \mathrm{C}$, with a total volume of $100 \mathrm{~mL}$, for 43 hours, and enzyme concentration $1 \%$ (b/v) while the evaporation process was carried out at a pressure of $0.8 \mathrm{~atm}$ with a temperature variation of $55^{\circ} \mathrm{C}, 60^{\circ} \mathrm{C}, 75^{\circ} \mathrm{C}$, and a total volume of $30 \mathrm{ml}$. The best results of the isomerization process was obtained at $60^{\circ} \mathrm{C}$ by water media with the concentration of fructose of $71.60 \mathrm{~g} / \mathrm{L}$ and the evaporation process at $60{ }^{\circ} \mathrm{C}$ obtained an increase in fructose concentration by $70 \%$ from initial fructose concentration and viscosity of 1.60 poise.
\end{abstract}

\section{KEYWORDS \\ Red sorghum \\ Isomerization \\ Evaporation \\ Fructose syrup}

\section{INTRODUCTION}

Recently, the food and pharmaceutical industry need a lot of sweetener to increase the taste of its products or as a mixture of syrup drugs. At this time fructose syrup often be used as an artificial sweetener because the level of the sweetness is higher than sucrose or granulated sugar which resulted in efficient way. In addition, fructose is a sugar contained in fruits so it is much safer to be consumed rather than sucrose (Permanasari et al., 2018). Fructose has the sweetness relativity higher than sucrose. It also has the ability to dilute and does not change to the crystal form (Parker et al., 2010).

Fructose can be made from sources of raw materials containing starch, such as corn starch, cassava, and several types of cerelia such as wheat and sorghum. One of the abundant raw materials is red sorghum flour, which is still not widely used as a carbohydrate substitute fordiabetics and special diets because it contains less gluten (Suarni, 2012). There are three methods of starch hydrolysis, acid hydrolysis, enzyme hydrolysis, and the combination both of 
them. In acid hydrolysis, starch is attacked randomly, if the conversion was done, most of the material converts to dextrose, but at the same time, an undesirable side reaction occurs. Acid hydrolysis begins to impart a bitter taste to syrup when conversion reaches $55-58 \mathrm{DE}$. Meanwhile, enzyme hydrolysis has advantages over acid hydrolysis due to the specific action of the enzymes and the smaller amount of by-product production (Shinde et al, 2004). In making the fructose syrup from red sorghum flour, red sorghum is being hydrolyzed into glucose syrup, then being isomerized into fructose syrup. The hydrolysis process includes two main stages, namely liquefaction with the help of alpha amylase enzymes and the saccharification process which is carried out with the help of glucoamylase enzymes. Liquid sugar as a result of hydrolysis of red sorghum flour is called red sorghum flour hydrolyzate sugar consisting of monosaccharides in the form of glucose, maltose, and dextrose. Hydrolysis from red sorghum starch with $40 \%$ substrate concentration obtained $185.435 \mathrm{~g} / \mathrm{L}$ glucose as the reducing sugar (Permanasari, et al., 2017). Mahreni and Sulistyowati (2004) made High Fructose Syrup from cornmeal flour with enzymatic process and obtained the fructose concentration $258.3 \mathrm{~g} / \mathrm{L}$ and conversion of 95.58\%. In some studies have been reported high fructose syrup production from cassava and sweet potato starch yielded fructose content of $28-29 \mathrm{~g} / 100 \mathrm{~g}$ (Johnson et al, 2010) and high fructose syrup production using tuber starch (arrowroot, Curcuma, xanthoma, and Dioscorea) as raw material has fructose content 16 - 17 (g/100 ml) Johnson and Padmaja, 2013). Furthermore, the isomerization process from red sorghum flour hydrolyzate sugar is carried out using glucoseisomerase enzymes to convert glucose into fructose and obtained the highest fructose concentration 174,7775 (g/L) with $2 \%$ (b/v) glucose-isomerase (Rahmawati, 2018).

Some researchers have carried out an isomerization process in order to make fructose syrup in which certain conditions are applied to obtain a high isomerization yield. In general, isomerization requires a long reaction time but produces relatively low yields so it is necessary to conduct isomerization research with a certain liquid media which can produce the highest yield. The use of organic solvent media at reaction temperatures close to room temperature $\left(27^{\circ} \mathrm{C}\right)$ can reduce enzyme stability (Vissuri and Kalibanov, 1986). Rahmawati (2018) hydrolyzed the red sorghum flour and isomerization in water media with glucose-isomerase enzyme concentrations of $2 \%$ (b/v), $\mathrm{pH} 8,48$-hours isomerization time and obtained the best fructose concentration of $174.78 \mathrm{~g} / \mathrm{L}$ with a conversion of $88.86 \%$. Maulani and Ramdhayani (2018) conducted a study on hydrolysis and isomerization of solid waste tapioca flour (onggok) in water media with a temperature of $6 \mathrm{o}^{\circ} \mathrm{C}, \mathrm{pH} 8.2$ for 43 hours and obtained the best yield of $37.82 \%$. Visuri and Klibanov (1986) conducted a study on the isomerization of sugar in the liquid phase on ethanol media with the ethanol concentration of $85-90 \%$ to obtain High Fructose Syrup (HFS) 55\%, at room temperature. The temperature of the operation can make glucose solubility low and enzymatic reactions slow but if the temperature is raised and too high will make HFS brown. Nilsson, et al. (1991) conducted an isomerization study based on d-glucose in ethanol-water media and temperatures of $40-70^{\circ} \mathrm{C}$ using glucose-isomerase enzymes. The highest fructose yield of $55 \%$ was obtained in the study with $70 \%$ ethanol concentration and $40{ }^{\circ} \mathrm{C}$.

Fructose syrup produced from the isomerization process is still very runny or contains a lot of water so it is necessary to do a concentration process to increase its fructose level and reduce its water content. The high water content in isomerized fructose syrup requires evaporation 
temperatures around $100^{\circ} \mathrm{C}$ but at this temperature fructose syrup are susceptible to damage in the form of caramelization. The best way to concentrate fructose syrup is by minimizing the possibility of caramelization by using evaporation at vacuum pressure to reduce the boiling point of the liquid. Bhanuwati et al. (2017), conducted a study on the process of evaporation of fresh milk into sweetened condensed milk using a rotary evaporator at low temperatures and a pressure of $0.8 \mathrm{~atm}$, temperature variations of $50{ }^{\circ} \mathrm{C}$ and $60^{\circ} \mathrm{C}$. In the operating conditions obtained fat levels increased from previous results to $6.62 \%$ and $6.65 \%$. The rotary vacuum evaporator is chosen because the area of the evaporation field is larger so the evaporating process is faster and the operating temperature is low and does not damage the sugar.

Based on the previous research related to the isomerization and evaporation, it is necessary to do further research on isomerization on organic solvent media in the proper operation. Hydrolizate sugar from red sorghum flour can be used to obtain the greatest yield.

\section{METHOD}

The methodology carried out in this study was by hydrolyzing the starch to form the substrate of hydrolyzate sugar, the isomerization method used catalytic enzyme glucose-isomerase to make the fructose syrup and used DNS and Seliwanoff method to analyze the content of the hydrolyzate sugar and fructose syrup.

\section{Preparation}

The initial preparation of this study was the manufacture of hydrolyzate sugar from red sorghum flour by enzymatic hydrolysis. The content of red sorghum flour can be seen in Table 1 and the enzyme characteristics used are shown in Table 2. The processes include gelatination, liquefaction, and saccharification. Substrate solution of $20 \%$ (b/v) with a volume of $300 \mathrm{ml}$ was heated to a temperature of $55^{\circ} \mathrm{C}$ for the gelatination process, namely cracking of the starch molecule. The next process was liquefaction by adding enzyme alpha amylase $0.33 \%(\mathrm{v} / \mathrm{v})$ and heated to a temperature of $95^{\circ} \mathrm{C}, \mathrm{pH} 7$, for 1 hour. The saccharification process carried out after liquefaction was completed by adding the enzyme glucoamylase $0.3 \%(\mathrm{v} / \mathrm{v})$ and heated at a temperature of $60^{\circ} \mathrm{C}, \mathrm{pH} 5$, for 2 hours. The result of hydrolysis was then referred to as sugar hydrolyzate. The hydrolyzate sugar was purified by adding $0.2 \%$ activated carbon and heated for 15 minutes at $80^{\circ} \mathrm{C}$. Next, the hydrolyzate sugar was filtered to get clear yellow liquid with $16 \%$ brix degree and $\mathrm{pH}$ 5. This hydrolyzate sugar was used as a substrate in the isomerization process.

Table 1. The Characteristics of Red Sorghum Flour (obtained from Jogjakarta)

\begin{tabular}{lc}
\hline \multicolumn{1}{c}{ Characteristics Observed } & Ingredients \\
\hline 1. Starch & $52.70 \%$ \\
-amilosa & $18.57 \%$ \\
-amilopektin & $34.13 \%$ \\
2. Fiber & $9.77 \%$ \\
3. Protein & $8.86 \%$ \\
4. Water Content & $0.8 \%$ \\
\hline
\end{tabular}


Table 2. The Characteristics of the Enzymes

\begin{tabular}{lccc}
\hline \multirow{2}{*}{ Enzymes Characteristics } & \multicolumn{3}{c}{ Enzymes } \\
\cline { 2 - 4 } & $\alpha$-amilase & Glucoamylase & $\begin{array}{c}\text { Glucose } \\
\text { isomerase }\end{array}$ \\
\hline Form & liquid & liquid & Granule \\
Activity & 2.029 & 2.968 & 2.358 \\
Density & 1.244 & 1.155 & - \\
Total viable count $(/ \mathrm{g})$ & $<100$ & $<200$ & \\
Coli Bacterial formed $(/ \mathrm{g})$ & $<4$ & $<4$ & \\
\hline
\end{tabular}

\section{Isomerization}

The main research was the enzymatic process of isomerization using glucose-isomerase as a biocatalyst. The substrate in the form of $100 \mathrm{ml}$ hydrolizate sugar was mixed with and was isomerized into fructose in the temperature variants of $27^{\circ} \mathrm{C}, 40^{\circ} \mathrm{C}$ and $6 \mathrm{O}^{\circ} \mathrm{C}, \mathrm{pH} 8.2$, with concentration of glucose-isomerase $1 \%(\mathrm{~b} / \mathrm{v})$ in two variety of organic solvent media, water and ethanol-water (70 \% ethanol). The comparison of the water-grade used was 1:2.5. Isomerization was carried out for 43 hours and being observed every 12 hours.

\section{Evaporation}

The isomerization results then centrifuged to separate a small amount of the sediment from the enzyme that was not dissolved. $50 \mathrm{ml}$ of isomerized fructose syrup was concentrated in the evaporator vacuum rotary device at a temperature variation of $55^{\circ} \mathrm{C}, 6 \mathrm{O}^{\circ} \mathrm{C}$, and $75{ }^{\circ} \mathrm{C}$ with a fixed pressure of $0.8 \mathrm{~atm}$ where the volume of the isomerized fructose syrup product evaporated as much as $30 \mathrm{ml}$ during 50 minutes.

\section{Reducing Sugar and Fructose Syrup Analysis}

Reducing sugar concentration of each sample (from hydrolysis and isomerization process) was determined by DNS method. $2 \mathrm{ml}$ of each sample was added by $3 \mathrm{ml}$ 3,5-dinitrosalicylic acid(DNS) solution and it was heated in boiling water for $15 \mathrm{~min}$ and fast cooled in ice water. Samples absorbance in room temperature was analyzed by spectrophotometer (LABO) with visible detector in wavelength of $540 \mathrm{~nm}$ (Miller, 1958). While the Fructose syrup concentration was analyzed by Seliwanoff method. It used resorcinol as the reagent and the analytical procedure was same with DNS method with heating time was 5 minutes (Roe et al., 1949).

\section{RESULT AND DISCUSSION}

\section{The Effect of Organic Solvent Media in Isomerisation Process}

The hydrolysis process of red sorghum flour obtained a hidrolizate sugar that was purified with activated carbon. Then, it was filtered and evaporated until the brix value was $16 \%$. The reducing 
sugar content as the glucose was determined by DNS method and obtained 191.75 g/L (initial sugar content). This sugar would be made as the substrate of the isomerization process.

Organic solvent used as a media in the isomerization process of hydrolyzate sugar of red sorghum flour into fructose syrup was water, and ethanol-water. The isomerization process in water media and ethanol-water media ( $70 \%$ ethanol), obtained a yield of $55 \%$ at $70 \%$ ethanol concentration and $40^{\circ} \mathrm{C}$ temperature (Nilsson et. al., 1991). The isomerization process carried out on ethanol media (85-90\%) with the temperature of $27^{\circ} \mathrm{C}$ obtained $55 \%$ fructose HFS (Visuri and Klibanov, 1986). The isomerization process in water media with the temperature of $60^{\circ} \mathrm{C}$ obtained the highest fructose concentration value of $174.78 \mathrm{~g} / \mathrm{L}$ (Rahmawati, 2018). From these preceding studies, it was selected media variations on water and ethanol-water media, as well as temperature variations at $27^{\circ} \mathrm{C}, 40^{\circ} \mathrm{C}$, and $60^{\circ} \mathrm{C}$ to determine the effect of organic solvent media and isomerization temperature on isomerization of hydrolyzate sugar of red sorghum flour into fructose syrup. The graph of changes in fructose concentration during the isomerization process in each temperature variation was presented in Figure 4.1 (a), (b), (c) as follows.

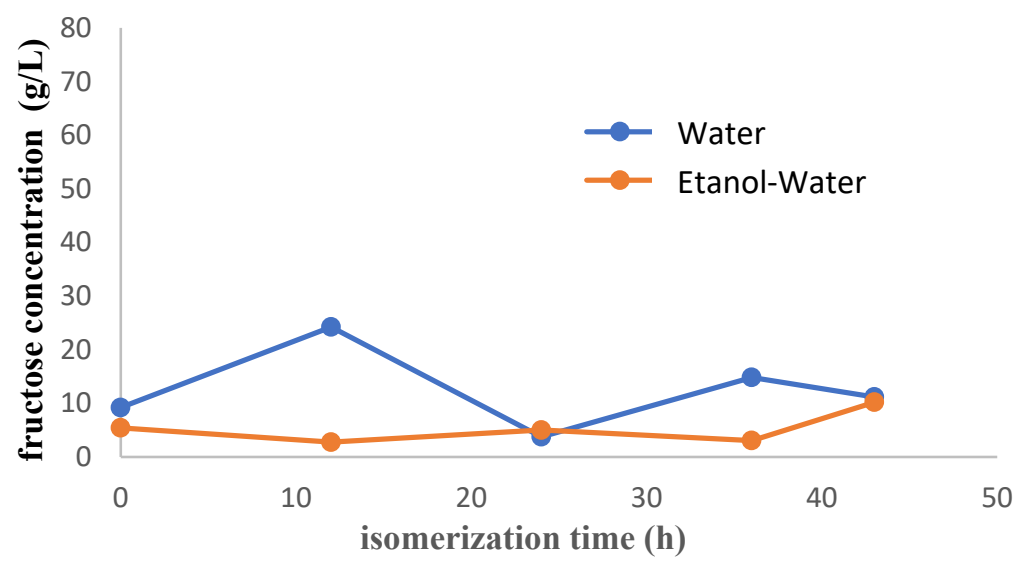

(a)

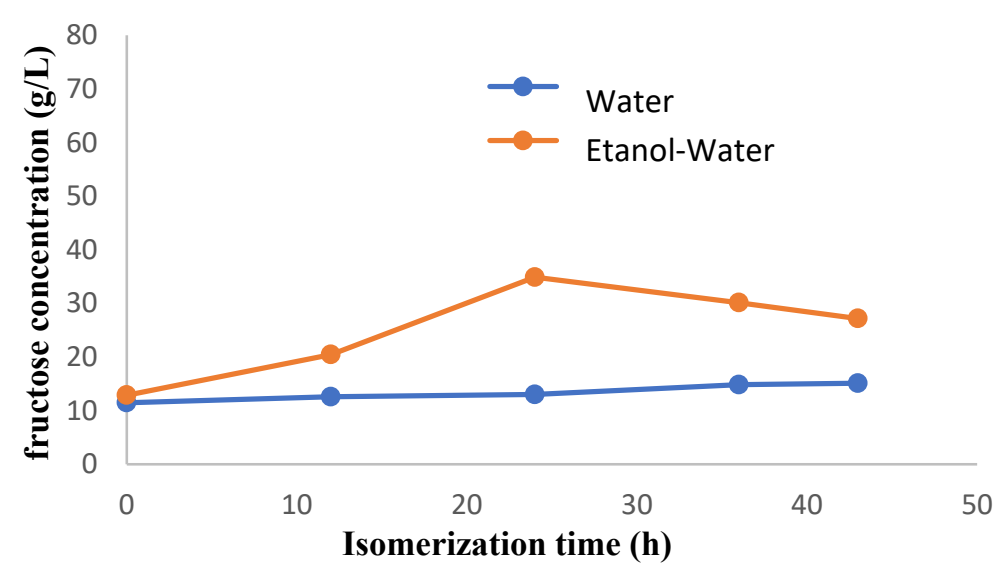

(b) 


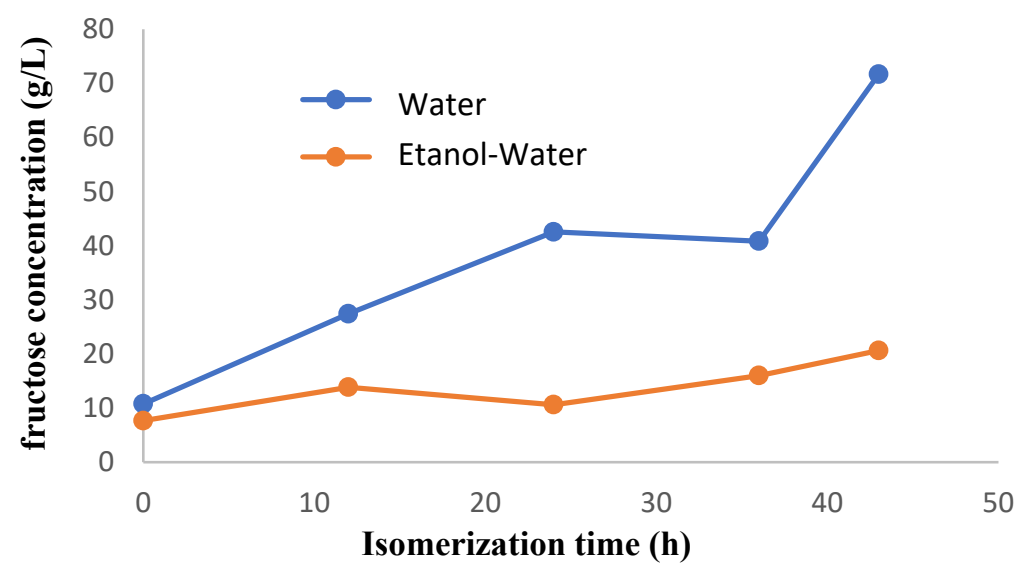

(c)

Figure 1. The curve of glucose concentration of hydrolyzate sugar with time by temperature variation of (a) 27 ${ }^{\circ} \mathrm{C}$, (b) temperature $40^{\circ} \mathrm{C}$, (c) temperature $60^{\circ} \mathrm{C}$

In Figure 1 (a) the isomerization process at $27^{\circ} \mathrm{C}$ (room temperature) with the water media, resulted in the highest fructose concentration at 12 hours is $24.23 \mathrm{~g} / \mathrm{L}$. This was due to the increase of glucose-isomerase productivity at low temperatures but risked in the increasing contamination of microorganisms (Jørgensen, et al., 1988). At 24 to 43 hours there was a fluctuating decline and incline, this was due to the reaction that occurs in the isomerization process was reversible so that the formed of fructose could return to glucose (Susmiati, et al., 2011).

In ethanol-water media, there was a decrease in fructose concentration at o to 12 hours. This was believed to be caused by an isomerization process that has not been occurred and still undergone hydrolysis process since the enzymes used ( $\alpha$-amylase and glucoamylase) in the previous hydrolysis process could not be separated from the media. The highest fructose concentration was obtained at 43 hours at $10.20 \mathrm{~g} / \mathrm{L}$. The presence of ethanol-water in the isomerization process could shift the equilibrium of the isomerization reaction but its reaction was relatively slow at $27^{\circ} \mathrm{C}$ (Visuri and Klibanov, 1986).

In Figure 1 (b) the isomerization process at $40^{\circ} \mathrm{C}$ for the water media, the highest fructose concentration was $15.14 \mathrm{~g} / \mathrm{L}$ at 43 hours. The increase of fructose was not significant, this was believed to be caused by low glucose-isomerase activity so it was necessary to increase the temperature to increase glucose-isomerase activity since enzyme activity will increase by the increasing of temperature to optimum temperature level.

In ethanol-water media there was an increase in the highest fructose concentration at 24 hours as much as $34.88 \mathrm{~g} / \mathrm{L}$, and decreased at 36 to 43 hours. This was probably due to the use of ethanol-water to a concentration of $80 \%$ could increase activity glucose-isomerase (Visuri and Klibanov, 1986). The optimum isomerization time for ethanol-water media was obtained at 24.96 hours. The combination of ethanol-water media (70 \% ethanol) at $40{ }^{\circ} \mathrm{C}$ produced a high concentration of fructose in a faster time compared to water media (Nilsson et al, 1991). 
In Figure 1 (c) the isomerization process at $60^{\circ} \mathrm{C}$ for water media, the highest fructose concentration was obtained at 43 hours as much as $71.70 \mathrm{~g} / \mathrm{L}$. The significant increase of glucose concentration occured at 36 hours to 43 hours, further research was needed in order to find out the phenomenon that occured in the 36 hours until the 43 hours period. Glucose-isomerase activity worked well on water media with the operating temperature of $60^{\circ} \mathrm{C}$ (Rahmawati, 2018).

In ethanol-water media, the activity of glucose-isomerase was low, it was believed that the combination of ethanol-water concentration and high operating temperature of glucoseisomerase in the market was susceptible to have side effects from ethanol use, the enzyme was poisoned (Nilsson et al, 1991), and was not added the glucose-isomerase activator substances, namely, magnesium ions (Visuri and Klibanov, 1986).

\section{The Effect of Organic Solvent Media in Isomerisation Process}

The effect of temperature to the final product of isomerization was presented on Figure 2.

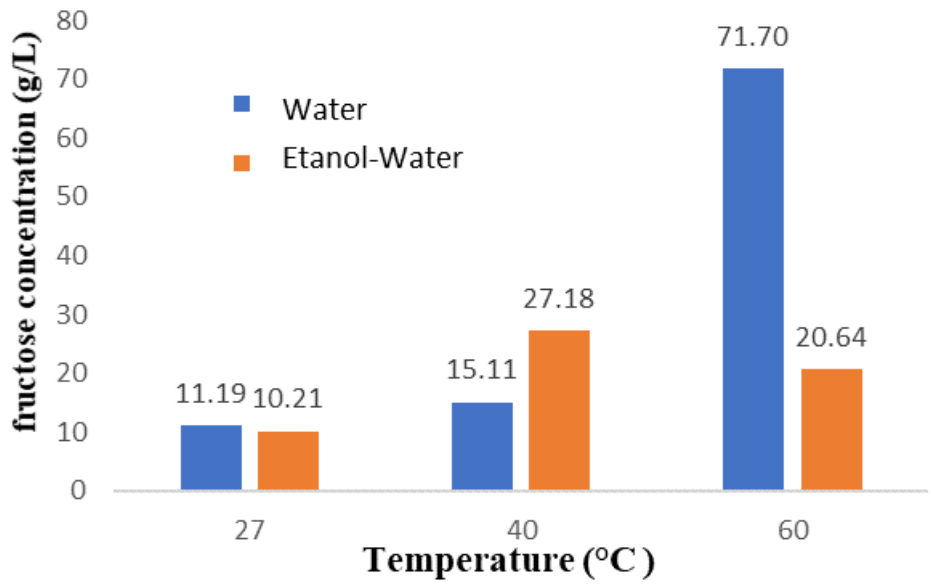

Figure 2. The concentration of fructose to the water and ethanol-water media temperature of isomerization process

According to Dekker, et al. (1991) the isomerization process was reversible so that the final concentration of fructose obtained depended on the reaction temperature, the higher the temperature, the higher the fructose concentration obtained. Based on the images in the water media obtained the final fructose concentration of the isomerization process of the highest red sorghum flour hydrolyzate sugar at $60^{\circ} \mathrm{C}$ at $71.70 \mathrm{~g} / \mathrm{L}$. One thing that could influence enzyme activity was temperature, so that at $60^{\circ} \mathrm{C}$ was the best condition for enzyme activity in breaking down the substrate into products (Rahmawati, 2018).

On the temperature of $27^{\circ} \mathrm{C}$ and $40^{\circ} \mathrm{C}$ the concentration of final fructose syrup obtained was lower, it was believed that in these conditions the glucose-isomerase activity did not work optimally. The isomerization reaction took place in an endothermic manner with a value in which heat was needed to produce the product but was limited by the ability of glucose-isomerase, because very high temperatures could damage the glucose-isomerase. 


\section{The Comparison of Hydolizate Sugar Isomerization and Pure Sugar (D-glucose)}

The best results in the isomerization process (water medium, temperature $60^{\circ} \mathrm{C}$ ), then compared with the isomerization of pure sugar as the substrate. This aimed to compare the performance of the isomerization process between the hydrolyzate sugar and pure sugar as the substrate. The Comparison of isomerization of hydrolyzate sugar and pure sugar was presented in Figure 3.

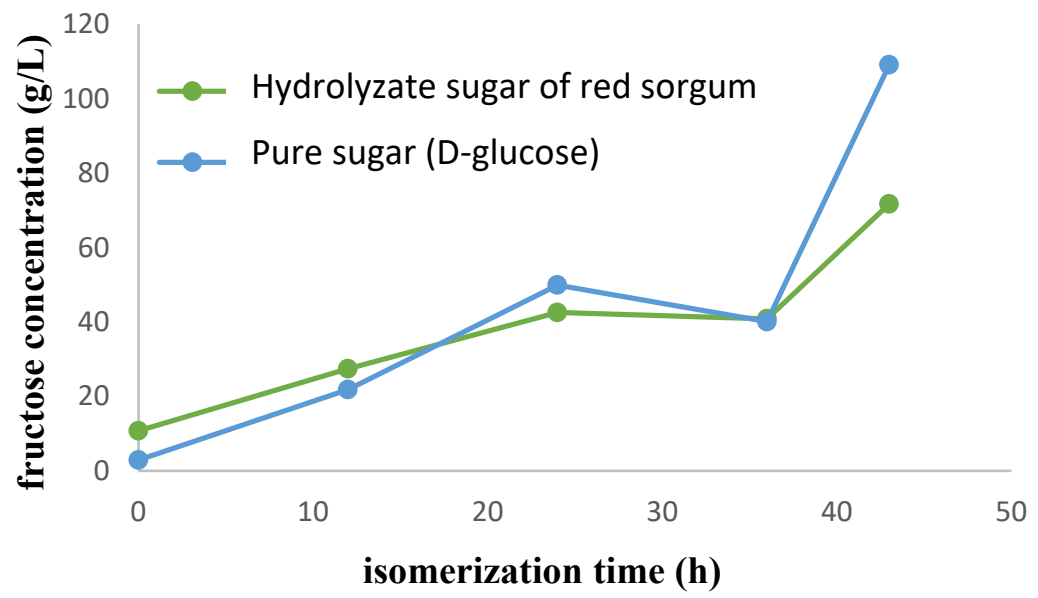

Figure 3. Curve ratio of fructose concentration to the time with water medium at temperature of $60^{\circ} \mathrm{C}$

In Figure 3 it could be seen that the concentration of fructose with a pure sugar substrate was greater than the substrate of the hydrolyzate sugar. This was caused by the impurity of the hydrolyzate sugar, which disturbed/ made the performance of the glucose-isomerase enzyme not as good as the pure sugar substrate (without impurity).

\section{Yield of Isomerization}

Yield of isomerization was calculated by compare the fructose content after the isomerization process with the initial glucose content at the isomerization process began. The best result of isomerization product was $71.70 \mathrm{~g} / \mathrm{L}$ of fructose content in water media with temperature $60^{\circ} \mathrm{C}$. It give the best result of isomerization yield 37.39\%. Hanover and White (1993) report that there are four types of high fructose syrup (HFS) based on technical data sheet (AE Staley Manufacturing Co, Decatur, IL; Cargill, Minneapolis; and ADM Corn Sweeteners, Decatur, IL) and the composition was shown at Table 3 and the physical properties was in Table 4 . In order to produce HFS 42, the fructose content must reach $42 \%$. While the yield of this study can be assumed as the fructose produced. The amount of yield almost reached $42 \%$. It was suspected that glucose-isomerase had not been carried out under the optimum and maintained conditions ( $\mathrm{pH}$ before and after isomerization). 
PERMANASARI ET.AL

Table 3. Typical composition of high-fructose-syrup (HFS) products*

\begin{tabular}{|c|c|c|c|c|}
\hline & HFS-42 & HFS-55 & HFS-8O & HFS-95 \\
\hline Solids (\%) & 71.0 & 77.0 & 77.0 & 77.0 \\
\hline Moisture (\%) & 29.0 & 23.0 & 23.0 & 23.0 \\
\hline $\mathrm{pH}$ & 4 & 3.5 & 3.5 & 3.5 \\
\hline $\begin{array}{l}\text { Carbohydrate (dry } \\
\text { solid basis) }\end{array}$ & & & & \\
\hline Fructose (\%) & 42 & 55 & 80 & 95 \\
\hline Dextrose (\%) & 53 & 42 & 18 & 4 \\
\hline Oligosaccharides (\%) & 5 & 3 & 2 & 1 \\
\hline Ash, sulfated (\%) & 0.05 & 0.05 & 0.03 & 0.03 \\
\hline Sulfur dioxide (ppm) & 2 & 2 & - & - \\
\hline
\end{tabular}

Table 4. Physical properties of high-fructose-syrup (HFS) products

\begin{tabular}{lcccc}
\hline & HFS-42 & HFS-55 & HFS-80 & HFS-95 \\
\hline $\begin{array}{l}\text { Density } \quad(\mathrm{kg} / \mathrm{rn} 3 \\
37 \cdot 77^{\circ} \mathrm{C} \text { at }\end{array}$ & & & & \\
As is & 1333.67 & 1373.21 & 1383.99 & 1385.19 \\
Solids & 946.63 & 1056.87 & 1054.47 & 1054.47 \\
Refractive index (at & 1.464 & 1.4786 & - & - \\
$20^{\circ} \mathrm{C}$ ) & & & & \\
Viscosity (Pa.s) & 0.16 & 0.76 & - & 0.575 \\
$27^{\circ} \mathrm{C}$ & 0.100 & 0.520 & - & 0.360 \\
$32^{\circ} \mathrm{C}$ & 0.075 & 0.360 & - & 0.220 \\
$38^{\circ} \mathrm{C}$ & 0.052 & 0.240 & - & - \\
$43^{\circ} \mathrm{C}$ & 0.035 & 0.160 & - & - \\
$49^{\circ} \mathrm{C}$ & $\leq 25$ & $\leq 25$ & $\leq 25$ & $\leq 25$ \\
Colur (RBU) & & &
\end{tabular}

\section{The Effect of Evaporation Temperature to the Fructose Concentration}

The evaporation process was carried out to remove the water media in the previous isomerization process in order to obtain concentrated fructose syrup. The evaporation process was carried out on the best isomerization product, which was in the water media with the temperature of $60^{\circ} \mathrm{C}$. The effect of temperature to the changes of fructose concentration in the evaporation process was shown in Figure 4. 


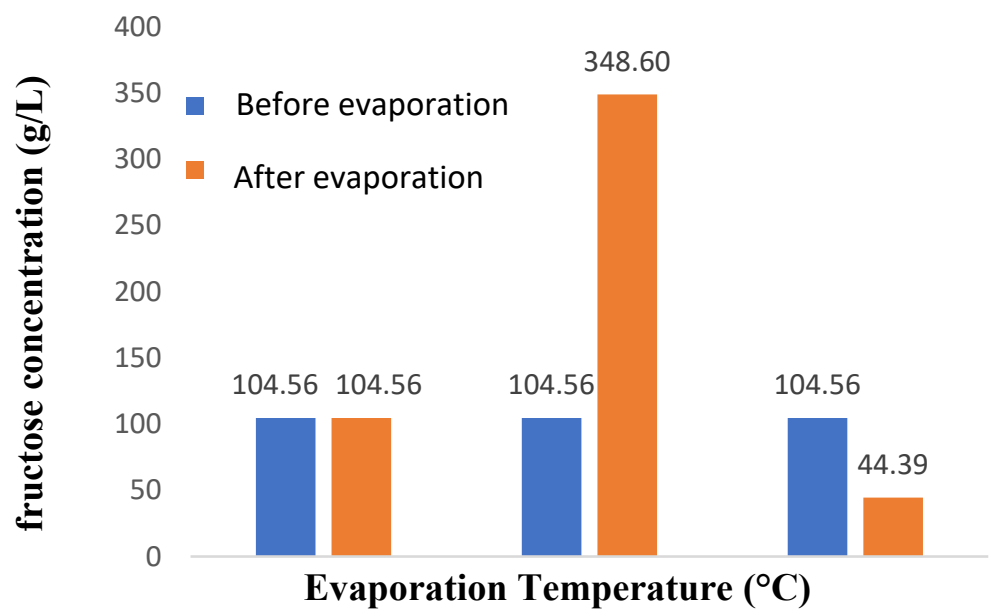

Figure 4. The concentration of fructose before and after evaporation with the temperature of $60^{\circ} \mathrm{C}$

In Figure 4 showed the best results of evaporation were obtained at $60^{\circ} \mathrm{C}$, where the fructose concentration increased by $70 \%$ from the initial fructose concentration after the evaporation process with the same time, pressure, and volume. The temperature was confirmed to be the most optimum because it not only increased the fructose concentration but also produced fructose syrup with a viscosity value of 1.60 poise at the ${ }^{\circ} \mathrm{C}$, where this value was the same as commercial HFS 42 in Table 4. The viscosity increased due to the water as the media undergone evaporation so that the longer the evaporation time the viscosity increased (Bhanuwati, 2017).

There was no separation of media in fructose syrup on the evaporation process at $55^{\circ} \mathrm{C}$, this was proofed by the absence of water stored in the receiver tube on the rotary evaporator so that there was no change in product concentration, while at $75{ }^{\circ} \mathrm{C}$ there was a decrease of concentration of fructose syrup which was caused by the high temperatures in the evaporation process which caused the damaged fructose.

\section{CONCLUSION}

Based on the results of the research, it could be concluded that the best operating temperature of the isomerization process occured at $60{ }^{\circ} \mathrm{C}$ in the water media which produced the highest fructose syrup concentration of $71.70 \mathrm{~g} / \mathrm{L}$ with the highest fructose yield of $37 \%$. While the best operating temperature of the evaporation process occured at $60^{\circ} \mathrm{C}$ with a fixed pressure which increased the concentration of fructose syrup to $70 \%$, viscosity 1.60 poise (according to commercial HFS 42).

\section{REFERENCES}

Bhanuwati, P. 2017. Teknik Pengawetan dan Emerging Proses Evaporasi. Practical report of Food Technology, Universitas Padjadjaran: Bandung. 
Dekker, K., Yamagata, H., Sakaguchi, K., \& Udaka, S. 1991. Xylose (glucose) isomerase gene from the thermophile Clostridium thermohydrosulfuricum; cloning, sequencing, and expression in Escherichia coli. Agricultural and biological chemistry, 55(1), 221-227.

Hanover, L. M., \& White, J. S. 1993. Manufacturing, Composition, And Applications of Fructose. The American journal of clinical nutrition, 58(5), 724S-732S.

Johnson, R., Morthy, S. N., and Padmaja, G. 2010. Production of high fructose syrup from cassava and sweet potato flours and their blends with cereal flours. Food Sci. Technol. Int., vol. 16, no. 3, pp. 251-258.

Johnson, R and Padmaja, G. 2013. Comparative Studies on the Production of Glucose and High Fructose Syrup from Tuber Starches. Int. Res. J. Biol. Sci., vol. 2, no. 10, pp. 68-75.

Jørgensen, O.B., Karlsen L.G., Nielsen, N.B., Pedersen, S., Susan R. 1988. A New Immobilized Glucose Isomerase with High Productivity Produced by a Strain of Streptomyces murinus. Starch/ starke 40. Nr.8, S. 307-313

Mahreni \& Sulistyowati, E., 2004. Pembuatan “ High Fructose Syrup ” Dari Tepung Maizena Secara Enzimatis ( The Making Of High Fructose Syrup From Cornmeal Flour Through Enzymization ). Proceeding of SNTPK VI. ISSN 1410-9891.

Maulani, L dan Ramdhayani, W. S. 2018. Pengaruh pH Pada Pemanfaatan Limbah Padat Tepung Tapioka (Onggok) Menjadi Sirup Fruktosa Secara Hidrolisis Enzimatis. Report of Diploma III Final Project, Dept. of Chemical Engineering - Poiteknik Negeri Bandung.

Miller, G.L., 1958. Use of Dinitrosalicylic Acid Reagent for Determination of Reducing Sugar. Analytical Chemistry - ANAL CHEM, vol. 31, no. 3, pp. 426-428.

Nilsson, K. G., Mosbach, K., \& Sakaguchi, K. 1991. Increased Yield of Fructose From Glucose Employing Thermophilic Xylose Isomerase In Water-Ethanol Mixtures. Biotechnology letters, 13(11), 787-792.

Parker, K., Salas, M., \& Nwosu, V. C. 2010. High fructose corn syrup: production, uses and public health concerns. Biotechnology and Molecular Biology Reviews, 5(5), 71-78.

Permanasari, A. R., Yulistiani, F., \& Djenar, N. S. 2017. Liquid Sugar Production from Red Sorghum Starch as Raw Material to Produce High Fructose Syrup (HFS). Advanced Science Letters, 23(6), 5775-5779

Permanasari, A.R., Yulistiani, F., Purnama, R.W., Widjaja, T., and Gunawan, S., 2018. The effect of substrate and enzyme concentration on the glucose syrup production from red sorghum starch by enzymatic hydrolysis. IOP Conf. Series: Earth and Environmental Science 160 (2018) 012002

Rahmawati, Atiqa. 2018. Isomerisasi Enzimatik Tepung Sorgum Merah Untuk Pembuatan "High Fructose Syrup" Thesis Report, Dept. of Chemical Engineering, ITS-Surabaya.

Roe, J. H., Epstein, J. H. and Goldstein, N. P. 1949. 'A photometric method for the determination of insulin in plasma and urine.', The Journal of biological chemistry. United States, 178(2), pp. 839845 .

Shinde, V.V., Jhala, A.S., Sayyah, M.Y., Jhala, Y.S., Vijayvergiva, N., Diwani, P.P., Mathur, G.K. 2004. Optimization of Process Condition for Preparation of Glucose Syrup from Sorghum Bicholor L Monech Starch Using Immobilized $\alpha$-Amylase and Gucoamylase Enzyme. Int. J. Chem. Sci.: 2 (3).

Suarni, 2012. Potensi Sorgum sebagai Bahan Pangan Fungsional., Iptek Tanaman Pangan Vol. 7 No.1, pp.58-66.

Susmiati, Y., Setyaningsih, D., \& Sunarti, T. C. 2011. Rekayasa Proses Hidrolisis Pati dan Serat Ubi Kayu (Manihot utilissima) untuk Produksi Bioetanol. Agritech, 31(4).

Visuri, K., \& Klibanov, A. M. 1987. Enzymatic Production of High Fructose Corn Syrup (HFCS) Containing 55\% Fructose in Aqueous Ethanol. Biotechnology and Bioengineering, 30(7), 917-920. 